УДК 373.2:331.548

DOI: $10.35619 /$ iiu.v1i10.178

\begin{abstract}
Янцур Любов
кандидат педагогічних наук, доцент, доцент кафедри педагогіки і психології (дошкільної та корекційної)

Рівненського державного гуманітарного університету,

м.Рівне, Україна

ORCID: 0000-0002-5532-6951

e-mail:Lybovyan1@ukr.net
\end{abstract}

Янцур Микола

кандидат педагогічних наук, доцент, завідувач кафедри технологічної освіти

Рівненського державного гуманітарного університету, м.Рівне, Україна ORCID: 0000-0001-5930-8788 e-mail:nic_yan@ukr.net

\title{
ФОРМУВАННЯ У СТАРШИХ ДОШКІЛЬНИКІВ ІНТЕРЕСУ ДО ПРОФЕСІЙНОЇ ДІЯЛЬНОСТІ ДОРОСЛИХ
}

\begin{abstract}
Анотація. В статті розглядається актуальна для сьогодення проблема профорієнтації , зокрема іiї пропедевтичний етап, який охоплює період дошкільного дитинства. Зосереджена увага на формуванні у старших дошкільників інтересу до професійної діяльності дорослих. В основу змісту цього процесу покладена класифікація професій Є. О. Клімова за предметом, метою, знаряддями та умовами праці. Здійснюючи елементарний аналіз професій за цією класифікацією, дошкільники повинні вміти виділяти три основні компоненти: назва професії, іiі основний зміст, користь професії для суспільства. При формуванні інтересу до професійної діяльності дорослих слід основну увагу зосередити на розвитку різностороннього інтересу до різних професій через активізацію пізнавальної діяльності дітей, надаючи перевагу активним формам і методам: екскурсіям, сюжетно-рольовим іграм, дидактичним іграм, іграм-вправам, різним змаганням, поєднуючи їх з традиційними методами, широко використовуючи сучасні технічні засоби та інформаційно-комунікаційні технології. У цьому віці варто проводити підготовчу робота 3 профорієнтації, результатом якої буде сформоване у старших дошкільників позитивне ставлення до праці і професійної діяльності. Показником інтересу старших дошкільників до праці дорослих $\epsilon$ їх ігрова діяльність, зокрема сюжетно-рольові ігри, в яких діти беруть на себе ту чи іншу роль.

Ключові слова: інтерес, профорієнтація, професійна діяльність дорослих, старші дошкільники.
\end{abstract}

Постановка проблеми. В умовах побудови незалежної держави гостро постає питання про підвищення ролі кожної людини. Потрібно зорієнтувати особистість на вибір виду трудової діяльності відповідно до своїх інтересів, здібностей, можливостей та потреби суспільства в кадрах. У вирішенні цієї проблеми важливе місце відводиться всій системі професійної орієнтації, яка перебуває в центрі уваги нашої держави. Про це свідчать Закони України «Про освіту», «Про дошкільну освіту», «Базовий компонент дошкільної освіти в Україні», «Концепція державної системи професійної орієнтації населення» та ряд інших державних документів. Отже, на сучасному етапі розвитку суспільства, коли стрімко зростає кількість різноманітних професій, окремі 3 яких $є$ особливо престижні, інші - не дуже, але однаково корисні, проблема профорієнтації особливо актуальна. Тому необхідно формувати в дітей інтерес і позитивне ставлення до різних професій. Це потрібно розпочинати якомога раніше, 
починаючи 3 дошкільного дитинства, оскільки саме цей вік особливо сприятливий для ознайомлення 3 професійною діяльністю дорослих та 3 метою формування позитивного ставлення до праці. Цьому сприяють, зокрема, такі вікові особливості, як підвищений інтерес до явищ суспільного життя, бажання брати участь у праці дорослих. Ми вважаємо, що при формуванні інтересу до професійної діяльності дорослих основну увагу слід зосередити на розвитку різнобічного інтересу до різних професій.

Аналіз останніх досліджень 3 проблеми. У психолого-педагогічній літературі інтерес розглядається як своєрідний сплав емоційно-вольових та інтелектуальних процесів, які підвищують активність свідомості і діяльності людини (Н. Морозова (1979). Інтерес до професій як складової професійного самовизначення розглядали Є. Клімов, С. Павлютенков, О. Сазонов, В. Симоненко, М. Тименко, С.. Чистякова, М. Янцур та інші. Педагогічний аспект проблеми інтересу розкриває Г. І. Щукіна (1971). Вона вважає, що інтерес формується всією системою навчання та виступає одночасно як вибіркова спрямованість психічних процесів, як прагнення, потреба особистості займатися саме тією діяльністю, яка приносить задоволення, як сильний збудник активності особистості, під впливом якого всі психічні процеси протікають особливо інтенсивно, як особливе вибіркове ставлення до навколишнього світу, що наповнене яскравими емоціями, вольовими прагненнями. Розвиток інтересів підпорядкований логіці вікового розвитку. Л. Гордон один із перших дав вікову характеристику інтересів дітей. Він відзначав, що для старшого дошкільного віку типовими мінливість, нестійкість, випадковість інтересів. Інтереси дітей дошкільного віку, зокрема, досліджувались психологами Є. Рибалко, Р. Тригер, П. Сирбиладзе та педагогами Н. Бойченко, Т. Куліковою, Л. Маневцовою, А. Сорокіною, І. Власовою, В. Андросовою, Л. Захаревич, Н. Постніковою, Л. Янцур. У дослідженнях отримало свій подальший розвиток і підкріплення положення, сформульоване Н. Добриніним і Н. Морозовою, про те, що інтерес сам має тенденцію розвитку і, водночас несе в собі величезні можливості розвитку дитини. Проблему ознайомлення дітей $з$ працею дорослих досліджували Л. Артемова, І. Красько, Т.Потапова, К. Пушкіна та інші. Саме питанню формування системних знань дітей про працю дорослих присвячені наукові дослідження В. Логінової, М. Крулехт. На думку Л. Артемової та Н.Кудикиної (1988), ознайомлення дошкільників 3 працею дорослих варто поєднувати із залученням їх до посильної діяльності.

Мета статті - розкрити особливості формування у старших дошкільників інтересу до професійної діяльності дорослих.

Виклад основного матеріалу дослідження. Світ професій дуже різноманітний, він постійно змінюється і зростає. В Україні їх нараховується більше 18 тисяч. Існує багато класифікацій професій. Усі їх можна поділити на «психологічні» та «непсихологічні». Найбільш актуальною як в теоретичному, так і в практичному застосуванні $\epsilon$ психологічна кваліфікація. Практична актуальність психологічної класифікації полягає в тому, що немає потреби знати кожну з декількох тисяч спеціальностей. Але, як відомо, знання професії є першою умовою ефективної роботи 3 профорієнтації. Вихід із протиріччя між необхідністю знань про світ професій та обмеженими можливостями знайомства з ними полягає у визначені груп професій, які відрізняючись одна від одної за об'єктивним змістом, були б спорідненими за психологічними вимогами до працівника. Класифікація професій, яка грунтується на залежності вимог професії до людини від предмету праці, з яким має справу працівник конкретної професії, а також від мети, знарядь (засобів) і умов праці, була розроблена Є. Клімовим (1990). На основі відмінностей у предметах праці всі професії поділено ним на 5 типів: «людина - природа», «людина - техніка», «людина - людина», «людина - знакова система» і «людина - художній образ». Слід зазначити, що вказані типи не можуть бути чітко розмежовані, і тільки умовно можна віднести конкретну професію до визначеного типу. За метою праці виділено 3 класи професій: гностичні 
(пізнавальні), перетворювальні і пошукові (винахідницькі). На основі відмінностей між знаряддями праці професії поділено на 4 відділи: ручні, механізовані, автоматизовані та функціональні. За умовами праці всі професії поділено на 4 групи: побутові, на відкритому повітрі, незвичайні умови та з підвищеною моральною відповідальністю. Ця класифікація покладена в основу підходу до визначення змісту процесу формування у старших дошкільників інтересу до професій дорослих.

Дошкільний вік особливо сприятливий для формування позитивного ставлення до праці. Цьому сприяють такі вікові особливості, як підвищений інтерес до явищ суспільного життя та бажання брати участь у праці дорослих. Тому, на думку Т. Поніманської (2013), розкривати дітям зміст праці дорослих необхідно не лише задля виконання завдань дошкільного виховання, а й для повноцінної підготовки до трудового навчання і профорієнтації у школі. За визнанням психологів і педагогів раціональною є така послідовність ознайомлення 3 працею дорослих: 1) накопичення фактів про процес праці, перетворення предмета праці, результати праці, створення уявлення про іiї значущість; 2) формування уявлень про людину праці, iї ставлення до праці; 3) формування уявлень про колективний характер трудової діяльності. Уявлення про працю однієї людини включає такі компоненти: 1) уявлення про робоче місце (кухня - у кухаря, кабінет чи лікарня - у лікаря); 2) про об'єкт праці (діти - у вихователя, хворі - у лікаря, глядачі - у артиста і т. д.); 3) про трудові дії і їх послідовність (кухар - нарізає овочі, робить салат, варить борщ, варить картоплю і т. п.); 4) про спеціальні предмети і знаряддя праці (ліки, таблетки, уколи - у лікаря); 5) про результати праці (матеріальні - готовий обід, випечений хліб і нематеріальні здорові люди, пасажири, доставлені на роботу водієм). Здійснюючи елементарний аналіз професій, дошкільники повинні вміти виділяти три основні компоненти: назва професії, її основний зміст, користь професії для суспільства.

Вивчення стану роботи закладу дошкільної освіти 3 ознайомлення старших дошкільників з професійною діяльністю дорослих засвідчило, що діти добре знають професію мами і тата, де і ким вони працюють. Більша половина дітей (60\%) були у когось $з$ батьків на роботі, розповідали, що вони роблять і що використовують для своєї праці. Проте $10 \%$ дітей не змогли назвати трудові дії мами чи тата, назвали лише їх професію. Знання переважної більшості дітей про професії обмежувалися професіями вихователя, вчителя, лікаря, міліціонера, пожежника, шофера, тобто тих професій, з якими вони найбільш знайомі і найчастіше зустрічаються в повсякденному житті. Лише 30\% дітей називали ще професії будівельника, інженера, перукаря, артиста, співака. Частина дітей знають фах банкіра, митника. 40\% старших дошкільників назвали трудові дії та результат діяльності представників таких професій, як лікар, який «лікує людей, допомагає хворим», перукар, який «робить зачіски, стриже волосся, робить людей гарними». Більшості дітям подобаються всі професії, які вони знають. 25\% старших дошкільників назвали професії лікаря, вчителя, міліціонера. Хоча є діти, які негативно висловлюються про деякі професії, наприклад, фах двірника, пожежника («вони можуть облити водою»), міліціонера («вони вбивають людей, тому і не подобаються»). У цих дітей сформовані неправильні знання про значення і зміст цих професій, їх користь для людей. 45\% опитаних дівчаток в майбутньому хочуть стати вихователем чи вчителем, а $50 \%$ хлопчиків міліціонером або водієм. Діти в переважно називали ті професії, про які мали певні знання, з якими зустрічаються в повсякденному житті. Здебільшого діти мотивують свій вибір: «хочу стати вихователем, щоб виховувати і навчати дітей», «стати міліціонером, щоб захищати людей, заарештовувати бандитів», «стати пожежником, щоб гасити пожежі, рятувати людей від вогню», «стати лікарем, щоб допомагати людям, лікувати їх від різних хвороб» і т. п. 15\% старших дошкільників не змогли мотивувати вибір своєї майбутньої професії. Такі бесіди з дітьми свідчать, що вони мають поверхневі знання про різні професії дорослих, трудові дії та результати їх діяльності. Загалом діти знайомі з різними видами праці. Кожною дитиною було 
названо від 3 до 13 професій. Безперечно, це не значить, що про кожен 3 напрямів професій дошкільники мають грунтовні уявлення, але широкий діапазон найменувань професій свідчить про зацікавленість дітей трудовою діяльністю людей. У відповідях старших дошкільників ширше всього представлені професії типу «людина-людина» $50 \%$ всіх найменувань, 3 них 48\% - хлопчики, 52\% - дівчатка. Найбільш популярна праця вихователя і лікаря, потім вчителя, продавця, поліцейського. На другому місці професії типу «людина-техніка» - 27,4\%, 3 них 66,2\% - хлопчики, 33,8\% - дівчатка. Найпопулярніші професії водія і таксиста, далі йдуть - будівельник, інженер, столяр. Професії типу «людина-природа» становлять $11 \%$, 3 них 60,7\% - хлопчики і $39,3 \%$ дівчатка. Серед них дошкільники виділили професії хлібороба і садівника. Лише 10,6 \% дітей назвали професії типу «людина-художній образ» (співака, артиста), з них 51\% - хлопчики і 49\% - дівчатка. Дошкільників більше приваблюють професії, які вони можуть бачити в повсякденному житті. Діти, які проживають в місті, мають недостатні уявлення про працю в сільському господарстві. Тому ми і маємо низький процент інтересу дітей до професій типу «людина-природа». Спостереження за іграми дітей старшого дошкільного віку продемонструвало, що вони переважно беруть на себе роль вчителя, вихователя, лікаря, шофера, співака. Тобто в своїй ігровій діяльності вони відтворюють працю тих дорослих, яка найбільш пов'язана 3 життєвим досвідом. Більша половина дітей використовують в іграх одну і ту ж професію протягом тривалого часу.

При формуванні інтересу до професійної діяльності дорослих варто основну увагу зосередити на розвитку різностороннього інтересу до різних професій, спираючись при цьому на розвиток активного ставлення дітей до тієї чи іншої професії, бажання дізнатися про неї більше, тобто формувати інтерес через активізацію пізнавальної діяльності дітей. Бажано не лише знайомити дітей з різноманіттям світу професій, але й прагнути, щоб вони усвідомлювали соціальну значимість кожного виду праці, його користь і важливість для людини. Звичайно, сформувати в дітей дошкільного віку всебічний інтерес до багатьох професій не можливо. Та і таке завдання на цьому етапі не висувається. Це обумовлено рядом факторів i, першочергово, віковими особливостями дошкільнят цього віку. Вони характеризуються малою диференціацією сприймання, які тісно пов'язані діями, практичною діяльністю та емоціями. У них слабо розвинута довільна увага, особливо ії стабільність. Діти конкретно мислять, мають схильність до механічного запам'ятовування, у них недостатньо розвинуті вольові якості, вони мають імпульсивний характер, примхливі, вередливі, довірливі, допитливі. У цьому віці формуються такі важливі новоутворення, як довільність, внутрішній план дій, рефлексія. Вибір професії здійснюється на рівні рольової гри на основі інтересу до зовнішньої сторони професії. Діти здебільшого орієнтуються на професії, з якими пов'язані найзначущі події в житті суспільства. Відбувається активне засвоєння суспільно цінних орієнтацій. Формою прояву інтересу до професії у дітей цього віку $є$ індивідуальна чи колективна гра, яка опирається на пізнавальні потреби. Дослідження з вікової психології свідчать, що в дошкільному віці пізнавальні інтереси у дітей переважно епізодичні. Вони виникають у певній ситуації, найчастіше під впливом заняття і майже завжди згасають, коли дитина отримала відомості, які задовольнили іiї епізодичну цікавість. 3 огляду на викладене, можна констатувати, що в цьому віці повинна проводитися підготовча робота з профорієнтації, результатом якої $\epsilon$ сформоване у старших дошкільників позитивне ставлення до праці і професійної діяльності.

Зважаючи на те, що основною особливістю дітей цього віку є ігрова діяльність, яка переростає у навчальну, то при формуванні у них інтересу до професійної діяльності дорослих перевага повинна надаватися активним формам і методам: екскурсіям, сюжетно-рольовим іграм, дидактичним іграм, іграм-вправам, усіляким змаганням. Безперечно, що їх потрібно поєднувати 3 традиційними методами, широко використовуючи сучасні технічні засоби та інформаційно-комунікаційні технології. 
Стратегію роботи з формування у старших дошкільників інтересу до професійної діяльності дорослих варто будувати на урахування їх можливостей та інтересів. Насамперед - закріпити і формувати нові знання про професії людей, які входять в найближче оточення дітей, поступово рухаючись від близького і частково відомого до більш далекого і невідомого. Від знайомства з професіями працівників дитячого садка і батьків до знайомства 3 працею абсолютно незнайомих чужих людей. Від знайомства 3 трудовою діяльністю лікаря, кухаря, двірника, 3 працею яких діти більш чи менш регулярно зустрічаються і спостерігають ії в своєму повсякденному житті, до знайомства $з$ професійною діяльністю хлібороба, комбайнера, гончара, праця яких дошкільникам знайома з розповідей батьків чи $з$ телевізійних картин. Для уточнення і розширення знань про професійну діяльність дорослих доцільно використовувати різні дидактичні ігри типу: «Відгадай, хто це?», «Назви професію від А до Я», а також профорієнтаційні вправи-ігри, що розширюють уявлення про різні сфери діяльності людини, поглиблюють наявні знання про працю, викликають зацікавленість у дошкільників, а також сприяють вихованню таких моральних якостей, як сумлінність, прагнення допомогти друзям. При формуванні інтересу до професійної діяльності дорослих старшим дошкільникам необхідно показувати переваги кожної професії, підводити їх до розуміння того, що всі вони потрібні і корисні в суспільстві, що кожна робота - це зусилля і наполегливість багатьох трудівників і що сумлінна праця дає людині справжню радість і насолоду. Із працею дорослих діти ознайомлюються в процесі демонстрації різних видів праці, пояснення їх значення під час спеціально організованих бесід, спостережень, екскурсій, занять, а також під час безпосередньої організації спільної діяльності дорослих і дітей. Дошкільники залюбки допомагають дорослим, переймаються їх настроєм, наслідують їх вчинки, отримуючи конкретні знання про професійну діяльність дорослих, уявлення про суспільну значимість праці, розвиваючи допитливість, інтерес до діяльності дорослих, проймаючись повагою до представників будь-якої професії. Спостереження за сюжетно-рольовими та творчими іграми дітей засвідчили, що старших дошкільників цікавить набагато більше професій. Вони беруть на себе роль вчителя, лікаря, водія, кухаря, пілота, перукаря, продавця, поліцейського, бібліотекаря, пожежника, садівника, будівельника, співака та інші.

Висновки і перспективи подальших розвідок. Таким чином, формування у старших дошкільників інтересу до професій дорослих є важливим етапом виховання особистості на моральних принципах поваги до праці людей. Широкий арсенал засобів i методів ознайомлення наймолодших 3 розмаїттям професій за класифікацією Є.О.Клімова, з конкретними трудовими операціями, знаряддями праці, 3 машинами і механізмами, які допомагають дорослим у їх професійній діяльності, спонукає дитину до самостійних дій, викликає прагнення наслідувати дорослих, формує найпростіші трудові навички, позитивне ставлення до самого процесу праці і всього, що 3 нею пов'язано. Надалі це може стати основою для свідомого і обгрунтованого вибору професії в шкільному віці. Тому потрібно детальніше дослідити вплив сучасних інформаційних джерел на формування професійних інтересів у дітей.

\section{СПИСОК ВИКОРИСТАНИХ ДЖЕРЕЛ}

Морозова, Н. (1979). Учителю о познавательном интересе. Москва: Знание. 47c.

Щукина, Г. (1971). Проблема познавательного интереса в педагогике. Москва, Педагогика. 352 с.

Артемова, Л., Кудикина Н. (1988). Ознайомлення дітей з працею дорослих. Київ: Радянська школа. $176 \mathrm{c.}$

Климов, Е. (1990). Как выьбирать профессию. Москва: Просвещение. 159с.

Поніманська, Т. (2013). Дошкільна педагогіка. 2-е вид., доп. Київ: Академвидав. $463 \mathrm{c}$. 


\title{
REFERENCES
}

Morozova, N. (1979). Uchitelyu o poznavatelnom interese [To Teacher about Cognitive Interest]. Moskva: Znanie. 47 s. (in Russian)

Shchukina, G. (1971). Problema poznavatelnogo interesa v pedagogike [The Problem of Cognitive Interest in Pedagogy]. Moskva, Pedagogika. 352 s. (in Russian)

Artemova, L.\& Kudykyna N.V. (1988). Oznaiomlennia ditei z pratseiu doroslykh [Introducing Children to Adult Work]. Kyiv: Radianska shkola. 176 s. (in Ukrainian)

Klimov, E. (1990). Kak vybirat professiyu [How to Choose a Profession]. Moskva: Prosveshchenie. 159 s. (in Russian)

Ponimans`ka, T. (2013). Doshkilna pedagogika [Preschool Pedagogy]. 2-e vyd., dop. Kyiv: Akademvy`dav. 463 s. (in Russian)

\section{FORMATION OF INTEREST TO THE ADULT PROFESSIONAL ACTIVITIES IN SENIOR PRESCHOOL CHILDREN}

\author{
Liubov Yantsur \\ Candidate of Pedagogical Sciences, Associate Professor, \\ Associate Professor at the Department of Pedagogy \\ and Psychology (Preschool and Correctional) \\ named after Professor T.Ponimanska, \\ Rivne State University for the Humanities, \\ Rivne, Ukraine \\ ORCID: 0000-0002-5532-6951 \\ e-mail: Lybovyan1@ukr.net
}

Mykola Yantsur Candidate of Pedagogical Sciences, Associate professor, Head at the Department of Technology Education Rivne State University for the Humanities, Rivne, Ukraine ORCID: 0000-0001-5930-8788 e-mail: nic_yan@ukr.net

\begin{abstract}
The article deals with the problem of vocational guidance that is relevant to the present, in particular, the propaedeutic stage, which covers the period of preschool childhood. The focus is on formation of the interest to the adult professional activities in senior preschool children. The content of this process is based on the classification of the professions of $\mathrm{E}$. $\mathrm{O}$. Klimov by subject, purpose, tools and working conditions. In carrying out elementary analysis of professions in this classification, preschoolers should be able to distinguish three main components: the name of the profession, its main content, the benefit of the profession for society.

When developing interest to adult professional activity, the focus should be on made on the development of diversified interest in different professions through the activation of children's cognitive activity, favoring active forms and methods: excursions, story-role games, didactic games, exercise-games, different competitions combining them with traditional methods, widely using modern technical means and information and communication technologies.

At this age, preparatory work on vocational guidance should be carried out, the result of which a positive attitude towards work and professional activity is formed in senior preschool children. An indicator of the interest of senior preschool children in the work of adults is their play activities, in particular, role-playing games in which children take on a particular role.
\end{abstract}

Keywords: interest, professional orientation, professional activity of adults, senior preschoolers. 